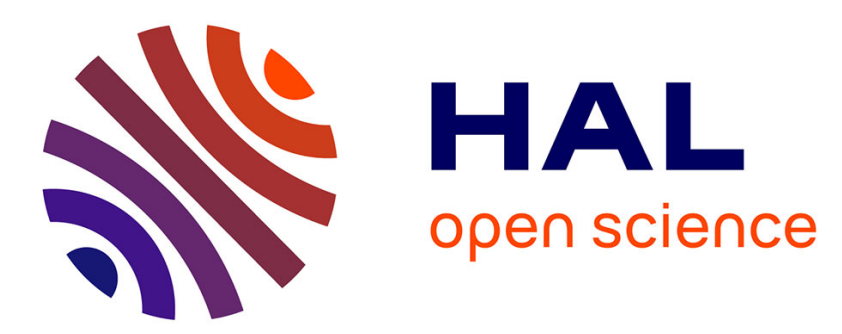

\title{
Labels of love: How migrants negotiate (or not) the culture of sexual identity
}

\author{
Michael Stambolis-Ruhstorfer
}

\section{To cite this version:}

Michael Stambolis-Ruhstorfer. Labels of love: How migrants negotiate (or not) the culture of sexual identity. American Journal of Cultural Sociology, 2013, 1 (3), pp.321-345. 10.1057/ajcs.2013.11 . hal-02123642

\section{HAL Id: hal-02123642 \\ https://hal.science/hal-02123642}

Submitted on 13 May 2019

HAL is a multi-disciplinary open access archive for the deposit and dissemination of scientific research documents, whether they are published or not. The documents may come from teaching and research institutions in France or abroad, or from public or private research centers.
L'archive ouverte pluridisciplinaire HAL, est destinée au dépôt et à la diffusion de documents scientifiques de niveau recherche, publiés ou non, émanant des établissements d'enseignement et de recherche français ou étrangers, des laboratoires publics ou privés. 


\title{
PRE-PRODUCTION AUTHOR'S COPY
}

\section{Labels of Love: How Migrants Negotiate (or Not) the Culture of Sexual Identity}

\author{
Michael Stambolis-Ruhstorfer ${ }^{1}$
}

\begin{abstract}
:
Drawing on in-depth interviews with 10 French lesbians, gays, and bisexuals (LGBs) living in the U.S. and 13 American LGBs living in France, this paper examines how national cultural context shapes the way LGBs understand and frame their sexual identity. The meaning these mostly White middle-class migrants attributed to their sexual identity was revealed - and in some cases changed - through cultural mechanisms provoked by crossing borders. Their journey gave them a unique perspective on the dominant national understandings of sexual identity in both countries. Through interaction, they discovered on the one hand, the French cultural expectations that individuals downplay their differences in the public sphere, and on the other, American cultural expectations that individuals align themselves with a minority category in the public sphere. As theories on the relationship between sexual identity and culture would predict, some respondents expressed feeling more comfortable with the sexual identity model of the country in which they came to embrace their sexuality. Half, however, preferred the model of the new context. These findings suggest that further theorization is necessary to understand why sexual identity appears to be highly contingent on culture for some people but seemingly independent of it for others.
\end{abstract}

\footnotetext{
${ }^{1}$ University of California Los Angeles, Department of Sociology, 264 Haines Hall, 375 Portola Plaza, Los Angeles, CA 90095-1551. Email: mstambolis@ucla.edu
} 
Keywords:

Culture, Identity, Sexuality, Migration, France, United-States

It is by now common knowledge that sexual identity - the way a person thinks about herself and who she is relative to her sexual behavior or desire - is socially constructed. We know that the meaning and significance of desiring and engaging in romantic and sexual relationships with people of the same or different sex has changed over time and varies geographically (Herdt, 1997; Valocchi, 1999). Much scholarship on contemporary variations in sexual identity juxtaposes Western and non-Western contexts (Altman, 2001; Berry, 2001; Wong, 2010), focuses on marginalized communities in the U.S. and other nations (Nagel, 2000), such as Blacks (Moore, 2011), Latinos (Ocampo, 2012), Asians (Poon and Ho, 2008) and immigrants of color (Amari, 2013; Decena, 2011; González-López, 2005; Provencher, 2011), or follows the trajectories of privileged Whites to "exotic" locales like Dubai (Collins, 2009; Walsh, 2007). Moreover, virtually no research examines the sexual lives and subjectivities of people migrating between Western nations and notable exceptions focus on racial, ethnic, and class disparities (Boston, forthcoming; Izienicki, 2009). Given the cultural differences and dynamics along the lines of race, ethnicity, class, and global power disparities in these research settings, it is logical to find effects on sexual identity.

This research landscape may inadvertently leave the impression that the meaning of sexual identity for White middle-class individuals in European and North American nations, such as France and the United States, is relatively similar. If such were the case, we would 
expect that sexual minorities migrating between these countries would experience little impact on their sexual identity. One of the first comparisons of its kind, this paper thus analyzes the narratives of such migrants in order to investigate whether there are systematic cross-national differences between France and the United States in the meaning of sexual identity on the one hand, and whether and how migration reveals the connections between national culture and sexual subjectivity on the other.

Closer inspection of the cultural and political organization of social differences and the public/private divide, both of which have implications for sexual identity, reveals variation among Western countries. In France and the United States, these differences are reflected, for instance, in the constraints social movements face in framing their actions (Fassin, 2001; Provencher, 2007; Stychin, 2003). In France, institutional pressures that reinforce universalism and anti-communitarianism make organizing around a gay identity challenging and subject to strong criticism by intellectuals across the political and sexual identity spectrum (Martel, 1996; McCaffrey, 2005). In the U.S., the history of social movements around specific categories of belonging and broader conceptions of a nation based on distinct collectivities make it possible to stake political claims on a sexual identity (Bernstein, 1997). The opposing position of sexuality on the macro and institutional levels in these countries suggest that individuals living in and migrating to them might come to sense and be informed by such differences in constructing their own sexual identities.

Given these cultural and institutional contexts, how do sexual minorities in the United States negotiate the social pressure that encourages the adoption of a gay identity when framing 
how they express their sexual identity? In the face of critiques against community-based rights claims, how do French sexual minorities make sense of and express their sexual identity? Finally, how do French and American sexual minority confront the identity models of each other's countries through migration and what do their experiences teach us about the relationship between culture and sexual identity more broadly?

To answer these questions, I conducted interviews with 10 French lesbians, gays, and bisexuals (LGB) living in the U.S. and 13 American LGBs living in France, 21 of whom were White and all of whom were middle-class. Because of their unique position having experienced the social norms of both cultures, these migrants were especially good at interpreting how cultural frameworks for conceptualizing sexual identity vary between France and the U.S. Migrants can make explicit what is usually only implicit; when they come to a new country, they cannot rely on their habitual cultural assumptions and, by navigating an unfamiliar social landscape, they can be more thoroughly sensitive than non-migrants to both cultures (Carrillo, 2004; Lamont and Molnár, 2002).

\section{Why compare sexual subjectivity in France and the U.S.?}

France-U.S. comparisons are sociologically useful because of the similarities and differences between these two nations (Lamont and Thévenot, 2000). After revolutions occurring at roughly the same time, both countries founded democracies upon the idea of the universality of "modernity, progress, rationality, liberty, democracy, human rights, and equality" which provides a general baseline of similarity for comparison (Lamont and Thévenot, 2000, p. 9). 
However, "French and American cultures show somewhat different formal characteristics that illuminate important theoretical issues" (Lamont, 1992, p. 2). Sexual identity is at the heart of the classic tensions between the public and private, the individual and collective within liberalism to which these countries have taken divergent political and philosophical approaches (Lamont and Thévenot, 2000; Pierceson, 2005; Brown, 2006; Fraser, 1989). The shape of these cleavages has already been documented for racism, sexual harassment, and gender equality (Bleich, 2011; Ezekiel, 2002; Lamont, 1992; Saguy, 2003; Scott, 2005). Sexual identity construction has yet to be compared empirically.

\section{Divergent social and political contexts}

The context in which individual sexual minorities come to make sense of their identities is illustrated by the French and American political and institutional stances that address the tensions within liberalism described above. French hostility to the notion that people can constitute distinct sub-national groups is expressed in terms of republican anti-communitarianism and universalism that favor assimilation and erasing social differences on the basis of race, ethnicity, religion, and sexuality in the public sphere. This is reflected in political battles over Muslim women wearing headscarves (Scott, 2009), immigration integration policies (Brubaker, 1992), and struggles over legal reform for sexual minority rights (Broqua et al., 2003; Gunther, 2009; Martel, 1996; McCaffrey, 2005; Poulin-Deltour, 2004). In the United States, rather than downplay social differences, policies emphasize the notion that individuals belong to and organize their political power through participation in and coalitions across distinct religious, 
racial, ethnic, sexual, or affinity communities. Examples of this approach include affirmative action (Harper and Reskin, 2005) and the development of race/ethnic, women's, and LGBT studies departments within the academy (Butler and Walter, 1991; Lovaas et al., 2006). These collectivities are not seen as antithetical to individual rights, liberty or the common good as they are in the French system.

French gay and lesbian activists must couch their arguments "in universal terms compatible with the French Republican model of assimilation and ... avoid criticisms ... of establishing 'special rights' for homosexuals" (Gunther, 2004, p. 346). For example, although the oldest and largest French HIV prevention organization, AIDES, was founded and run almost exclusively by gay men, its organizers decided to frame their organization as identity and community neutral while their U.S. counterparts at the Gay Men's Health Crisis did just the opposite. Furthermore, French activists struggled to eventually import and establish a French version of the U.S. anti-AIDS activist organization Act-Up because of resistance to their identity politics rhetoric from AIDES, French authorities, and intellectuals (Broqua, 2005). Similarly, although the 1970s saw the rise of several radical gay-identified organizations (Jackson, 2009), the gay movement's stance since then has moved from "revolutionary to inclusionary" (Fillieule and Duyvendak, 1999). For instance, the political battle around the passage of the 1999 Pacte Civil de Solidatirité ( $\mathrm{PaCS}$ ) law, which allows individuals, regardless of their sex, to enter into civil unions, shows how lawmakers, and the activists who supported them, had to draft the bill without mentioning homosexuality as a specific category (McCaffrey, 2005). Furthermore, the bill's opponents - of all political stripes - warned that allowing same-sex unions would end the 
sexual neutrality of the republic, defy the sexual duality of human nature, and signal the French state's capitulation to "American-style" identity politics. The social and political climate has evolved rapidly in the last fifteen years, with, for example the recent recognition of marriage and adoption rights for same-sex couples (2013-404 Code Civil [2013]). Increasing social and political integration could make identity-based rights claims less difficult but, depending on how these reforms are debated, they could reinforce the idea that because sexual minorities have achieved formal equality, they should further strive to assimilate into French universalism.

U.S. organizations fighting for legal equality for sexual minorities have traditionally drawn on the rhetoric of multiculturalism and civil rights to shape activism (Bernstein, 2011; Haider-Markel and Meier, 1996; Mucciaroni, 2008). These tactics generate and encourage rhetoric of group-based rights, membership in a distinct "gay community," and sexuality identity as a category for political action. Since the 1970s, organizations have argued that sexual minorities constitute a group of individuals whose status, like that of gender or race, should not be the grounds for discrimination (Rimmerman, 2002). For example, in front of state and federal courts and legislatures, lawyers and movement representatives push for extending existing statutes to sexual orientation that already protect women and racial/ethnic minorities against workplace discrimination and hate-crimes (Biegel, 2011). They argue that sexual minorities, like Blacks and women, are a historically oppressed group. Opponents draw on similar frames to argue against the legal equality for sexual minorities when they state that sexual orientation cannot enjoy legal protections because, unlike race or gender, it is not a deeply immutable and fundamental part of one's identity (Mucciaroni, 2008). The idea that sexual minorities constitute 
a distinct group is also reflected in reactions to the AIDS epidemic out of which grew gay community-based clinics and contemporary approaches to "LGBT health." As LGBT activism in the U.S. evolves, organizations are attempting to overcome the multicultural model by emphasizing the plurality of identities within the gay movement and building bridges beyond it (Ghaziani, 2011). Yet these efforts to move to "cultural pluralism" (Seidman, 2002) rather than multiculturalism still take for granted the notion that collective sexual identity exists.

\section{Constructing sexual identity}

These national contexts suggest that having a strong and visible public gay identity is politically fraught in France (Provencher, 2007; Amari, 2013) while in the U.S. refusing to adopt such an identity might be difficult. To analyze the way individual sexual minorities living in these divergent national political and cultural contexts develop an understanding of what it means to be attracted to someone of the same sex and the place that attraction has in their everyday lives, I draw on the concept of identity work. People perform "identity work" in order to understand how their sexuality fits into their sense of sexual self (Kimmel, 2007), their connection to their community, and their social location (Brekhus, 2003; D'Emilio, 1998; Eliason, 1996; Moore, 2011). For instance, among other questions, people who are attracted to someone of the same sex determine if they want to label themselves, if they should reveal that to others, if that attraction should be important to how they see themselves, or if they should take a political stance based on that attraction.

This identity work also involves complex negotiations between people's sexuality and the 
other qualities of who they are, including their religion, gender, class status, race/ethnicity, and nationality. For instance, in interviews, Moore (2011) found that a lesbian couple of Haitian descent in the U.S. struggled with their sexual and ethnic identities as they planned to publicly celebrate their union because their families told them that such open displays of same-sex love were "American" and antithetical to Haitian culture. Struggles like these may also play out for privileged sexual minorities in both contexts as they negotiate what it means to be both gay and French or gay and American.

To conceptualize how identity work is shaped by cultural context, I argue that individuals use categories, labels, symbols, language, and images (Swidler, 1986) provided by their structural situations to interpret the meaning of their sexuality. Also called "sexual scripts" when applied specifically to sexuality (Gagnon and Simon, 1973), the analytical frameworks, or "cultural repertoires" (Lamont and Thévenot, 2000), people use to understand and label themselves as say, "straight" or "gay," vary transnationally. They are embedded within institutions, like the law, schools, or families, and constrain and enable the kinds of arguments, ideas, and justifications people use in everyday and political settings (Saguy, 2003). For that reason, the meaning and categories of sexual identity are inextricably tied up in the broader political debates that I highlight above.

People may be able to think beyond these "mental maps" (Lamont, 1992) but they also learn what kinds of categories their peers will understand and respond to (Saguy, 2003). However, when they change contexts, they may also carry these cultural resources with them even as they learn, in interaction with individuals and institutions, about the cultural repertoires 
of their new settings (Carrillo, 2004). Migration may thus provide people with unique opportunities for sexual identity construction, or, at the very least, render the conditions of their identity work more visible.

\section{Sexuality and migration}

International migrants' experiences of travels across borders reveal how the cultural frameworks and symbolic resources that structure the meaning and practice of sexuality depend on local contexts (Lamont and Molnár, 2002; Manalansan, 2003; Patton and Sánchez-Eppler, 2000). The sexuality of migrants, a domain only recently taken up by sociologists, enables us to see how "bodies carry with them ideologies, practices, desires, longings, and imaginings about ways of enacting sexuality differently in faraway locations" (Carrillo, 2004, p. 68). Migrants come with a set of ideas, including about what they hope their host country will bring them, which then confronts the expectations and ideas of those in an unfamiliar setting. Mexican and Latin American migrants to the U.S., for example, are exposed to different norms and, in some cases, distance from family and friends, which transforms their sexual identity, behavior, and sometimes even desires (Cantú et al., 2009; Carrillo, 2004; González-López, 2005). They are also simultaneously expected to publicly affirm a gay identity that assumes access to racial and class privilege (Decena, 2011).

Race, ethnicity, language, inequality, and culture play a critical role in determining changes in the sexual practices and ideologies in the lives of migrants. For example, Latin American migrants to the U.S. can be conflicted between the expectations of their communities 
and the sexual desires of their children who sometimes hope to behave like non-migrants (González-López, 2005). In France, sexual minority children of North African immigrants express feeling caught between solidarity and rejection because of racism and exoticisation from native born French sexual minorities on the one hand and the religious and cultural expectations of their parents on the other (Amari, 2013; Provencher, 2011). Similarly, in the U.S., recent Polish male immigrants who have sex with other men are only likely to admit such attractions and affirm a gay identity if they leave their ethnic communities (Izienicki, 2009). Power, race, and status also structure how White gay-identified North American and European "expatriates" in Manila, who migrate with the specific intention of discovering "exotic" kinds of sexual expression, experience their sexual identity (Collins, 2009). Similar factors motivate White gay Polish men to migrate to the UK with the hopes of meeting Black men (Boston, forthcoming). In these cases, much like with White partners of Latin American migrants, sexual desire and practice is racialized and enacted between individuals of unequal social status.

Underlying these works is the idea that White privileged migrants moving between wealthy Western nations such as France and the United States would probably experience little friction, questioning, or negotiation between their home culture and their host cultures in the realm of sexual identity. Such a stance assumes a relatively uniform model of sexual identity in both contexts. Yet one of the key insights of this literature, and the theoretical motivation for this paper, is that an excellent method for understanding the relationship between culture and sexuality is to look to the experiences of migrants. 


\section{Methods}

[Insert Table 1 about here]

During the winter of 2009-10, I conducted 23 in-depth interviews with French and American sexual minorities. The sample consists of ten French people in the U.S. including seven gay men, two lesbians and one bisexual woman and thirteen Americans in France including ten gay men, three lesbians, and one bisexual woman. To be included, individuals had to be adults, self identify as gay, lesbian, bisexual, queer, homosexual, or attracted to people of the same sex, be raised in the home country, move to the host country and have lived there or be currently living there for at least 6 months. I use "theoretical sampling" in order to build theory about the relationship between culture and sexual identity rather than to generalize about sexual minorities or migrants between the two countries (Glaser and Strauss, 1967; Miles and Huberman, 1984). Respondents came from and went to a wide range of regions in both countries. In addition to large cities, with visible gay and lesbian populations, over half of the sample came from or went to small cities or rural areas without such LGB visibility. This diversity allows me to speak beyond the experiences of, say, people moving between New York and Paris. The sample consists of seven women and sixteen men. Because of the underrepresentation of women, I do not conduct comparisons across gender and am therefore unable to address the gender differences that the literature on migration and sexual identity suggest are salient (HondagneuSotelo, 1994).

I recruited candidates through online forums, social networking websites, university 
LGBTQ resource centers, "expatriate" organizations, and contacts from fieldwork sites in both countries. Because LGB international migrants are a relatively "hidden population," I used "respondent driven sampling" by asking interviewees to recommend me to their acquaintances who matched the selection criteria (Heckathorn, 2002). Five respondents knew each other through friendship networks while the other eighteen were recruited independently.

The same interview protocol was used for all interviewees and covered questions about motivation for migration, social life, sexuality, sexual identity, and opinions of political issues. I conducted the interviews in person or using video-conferencing technology and in the language of the interviewee's choice. Interviews ranged from 90 to 120 minutes, were audio recorded, and relevant sections transcribed. With word and data processing software, I first used inductive coding to analyze the transcripts and then recoded the interviews and created theme sheets that regrouped the pertinent data from each interview according to specific narratives common among interviewees.

\section{Discovering French and U.S. sexual identity models}

The interviews revealed that these sexual minorities migrating between France and the United States encountered in each country a distinct, salient, national mode of organizing sexual identity. As a result of the cultural dislocation caused by moving across the Atlantic, they had to learn through interaction and trial and error about the norms, practices, and social expectations of their new surroundings. They used their habits from home, of which they became acutely aware upon moving, as a basis for comparison between differences of both cultures. Beyond the 
obvious French and American cultural differences any migrant or tourist might experience in things like eating habits, patterns of friendship, or esthetics, these sexual minorities were particularly confronted with differences in gender, sexuality, and identity. As Dan, a 24-year-old American from Louisiana, who lived in several French regions over three years before our interview, explained, "gender questions and questions about sexuality are just not approached in the same way." Specifically, all of the respondents said that they learned that they were expected to resist labels and downplay a minority sexual identity in France while in the U.S. they should publically align themselves with a rigid identity category.

These migrants were confronted with the same pressures as gay social movement organizations in France to emphasize universality and assimilation to a national identity rather than highlight minority sexual difference. Xavier, a 27-year-old gay French man who moved to Washington, D.C. from Southern France when he was 13 and then went back to Paris for college, gave a typical description of this pressure: "the ideology in France is that you're French before anything and we don't care if you're anything else," including your sexuality. He described a debate he had with his French gay and lesbian friends:

Some of them would basically say, "You know, if there wasn't so much homophobia, you know, I wouldn't call myself gay because I think that putting yourself in a category like that reduces you to an identity and it's reductive." You know, they like uniformity before all. It sort of meshes well with the republican ideal. We're all citizens of the Republic.

As Xavier described it, French sexual minorities perceive gay identity as, at best, a tool to 
combat exclusion, but ultimately limiting, dangerous, and a barrier to national community integration. Marie, a 37-year-old French lesbian who moved in 2001 from Aix-en-Provence to Austin, Denver, and eventually Los Angeles for her law career, explained that French resistance to visible gay identity was expressed through rejection of the notion of gay community. She described how her French lesbian friends thought about these issues:

What they call "communautarisme" or "ghettoization" or Balkanization of the gay community it's because it's in the open in the U.S. Not hiding it. ... While in Paris, at least my sense was, it exists, but people are so, almost ashamed of being part of a community, it's so anti-norm, especially if you're a lefty, it's really seen as a kind of denial of the French identity of this notion of citizenship and universalism that people pretend that they are not part of a community. Publicly recognizing and organizing oneself into a community around sexual minority status is problematic in France because, as Xavier stated, people believe it "threatens to break up the French polity." Furthermore, as these respondents described it, skepticism and stigmatization of the gay community stem from broad principles of national unity that have appeal across the political spectrum.

Rather than reflect opprobrium of homosexuality per se, the ideology the respondents described requires that one remain strictly sexually unmarked in the public sphere. They learned that being public about one's sexual identity or revealing it to others, even to close friends and family who are known to be accepting of homosexuality, was not expected in France and sometimes unacceptable. Danielle, a 29-year-old originally from Florida who had just moved 
back to France to pursue a master's degree and be with her girlfriend, after having lived there for four years, explained: "I've heard French people say to me that, well, if you're gay or not gay, that's something you keep to yourself. It's not something you announce to somebody." Bénédicte, a 38-year-old from Paris who moved to Los Angeles in 1998 to pursue her acting career, explained that revealing one's sexual identity is not necessary: “In France it's understood. We know it. It's fine. We accept it. We don't spread it out... They are who they are; they don't need approval. They don't need affirmation or acceptance. It's already understood. We are all who we are."

In contrast to French imperatives, the respondents learned that in the U.S. they were expected to align themselves with an identity category, foreground it in their everyday interactions, and embrace the idea of a gay community. They perceived that sexuality was generally more important and had higher stakes. Dan, for instance, explained that sexuality is a "big deal" in the U.S. When children reveal their sexual identity to their parents, "It's dramatic," he said, but in France "[it's a] transition to that just being part of the person [and] another part of that family member." In the United States, respondents said that sexuality was a major part of people's lives and not just a minor, insignificant characteristic. These stakes were, however, a source of strength for combatting stigma and fighting for rights. For example, David, a 34-yearold who had moved to Pau from Amherst, Massachusetts for graduate school seven months before our interview, told me "I don't mean to say that [the French] don't seem to have like the pride that we do in the U.S. or whatever but like they don't seem to want to fight for it as much." The respondents' most common observations about the United States was that, unlike in 
France, one could speak of having multiple and equally important identities rather than one universal national identity. "I don't feel there is one way to be an American," Xavier explained, "You can hyphenate your identity in the U.S. while you can't really in France." Yet the possibility of hyphenation necessarily implied being forthcoming about one's sexuality. Danielle explained, "In the U.S. people want to know your label immediately." While in France, Danielle felt that people were respectful for her private life, but, in the U.S., she said, "I feel like Americans need immediate information about you. Like it's expected in the U.S.” Bénédicte, confronted this unfamiliar pressure to be, in her words, "more loud about it," on film sets when she was working in Los Angeles. She said, "Here it seems that you have to announce it. You have to write it on your forehead." She was surprised at how easily acquaintances and colleagues would tell her they were gay or - mostly disturbingly for her - would ask her if she was.

\section{Embracing and rejecting French and U.S. sexual identity models}

None of the interviewees said they moved abroad because of their sexuality; they cited professional, educational, or economic motivations. Yet all of the respondents from both groups told me that leaving their home countries forced them to think about the meaning of their sexuality in some way. Experiencing first hand the specific national models of sexual identity described in the above section allowed them to question their assumptions and brought to light the expectations and ideas about sexuality into which they were socialized. Given the French deemphasis of sexual minority status in the public sphere, we would expect French respondents to feel uncomfortable in the U.S. where labeling and vocal self-identification are encouraged. 
Inversely, we would expect U.S. respondents - accustomed to visible and bounded sexual identity categories - to find French notions of public discretion and sexual ambiguity frustrating.

Yet their experiences in their new contexts revealed two distinct groupings of reactions. Some found the experience of living in a new country to be particularly liberating while others felt constrained by the model of sexual identity in their new context. Nine respondents - four French and five American - explained that they felt out of place, uncomfortable, or frustrated with expectations people had for their sexual identity in their host countries. Although some expressed being happy living abroad for reasons that motivated them to leave in the first place, they said that their sexual identity was burdened in ways it would not have been back home. Their narratives support the idea that cultural repertoires of evaluation become an integral part of how people think and shape their ideas, perceptions, and experiences even when they move abroad.

However, in contrast to this group, fifteen respondents - six French and eight American said that moving abroad was a source of opportunity for learning about themselves in new ways and came to prefer the model of sexual identity of their host country. Five respondents - three French and two American - went so far as to say that moving abroad triggered an acceptance or affirmation of their same-sex attractions that they were not fully aware of before moving. While classic characteristics of migration, such as distance from family and friends, facilitated these changes (D'Emilio, 1998; Chauncey, 1994), this group of respondents also attributed them to specific qualities in the French and U.S. models of sexual identity. In other words, their experiences suggest that some people moved beyond their socialization and rejected the cultural 
repertoires of their upbringing in formulating their sexual subjectivities. However, in such circumstances, these sexual minority migrants spoke of conflict between their national and sexual identities and had difficulty reconciling their sexual selves with their origins.

The sections below analyze: 1) those individuals whose preferences conflict with their current location but concord with the sexual identity model of their upbringing; and, 2) those whose preferences align with their current location but discord with the model of their country of origin (see Table 2). I explain the aspects of the models that lead the respondents to prefer one to the other and analyze the complex relationship between national and sexual identity. [Insert Table 2 about here]

\section{When country of origin and sexual identity model concur}

Some French respondents in the United States expressed resentment and resistance to norms like pressures to reveal their sexual identity and label it. Bénédicte, for instance, told me she felt Americans are always "trying to find the dirt" about other people. She perceived this curiosity as intrusive and rude. As a rule, she preferred what she considered a French separation of public and private lives. She said, "I am open about [it]. I'm not hiding it but I'm not wearing the sticker, 'I'm gay.' So if people ask, I'm like, 'That's my personal life and if we become friends, yes, they're gonna know I'm gay, but whether I'm gay or not, I'm not sharing my personal life.' I separate the two.” Furthermore, she felt pigeonholed by sexual identity labels. She said given the choice, she would rather not identify as a lesbian. Instead, she felt that sexuality was the meeting of "souls" and that thinking in terms of gender was too limiting. 
Olivier, a 26-year-old who was a graduate student teaching assistant for a year in Arizona, also found a frustrating paradox in the American approach to homosexuality where, "on the one hand it's a lot more accepted than in France but on the other hand it's less accepted too." He said, "I have the impression that in the United States as long as you fit into a box, it's ok, but as soon as you blur the line between categories, it's very complicated." Sexual ambiguity, mystery, and subtlety become difficult in a system where sexual behavior is labeled and lived as an identity - even with broad or intentionally destabilized categories like queer - and used as an organizing force to combat stigma. Olivier started to feel limited by the label gay as he interacted with his colleagues, friends, and students because he felt they were holding him to stereotypes: "In the United States, people really fight for an identity [and] there really is the sense that you have the right to exist with your differences. But it's also a country for me that is very normative. For me, I realized that people really had ideas about what a gay person should be." In France, Olivier was used to interacting with people according to the assumption that sexual identity stays in the background; being in a setting where he was suddenly considered a member of a group gay men - he felt limited and pegged. The opportunity to play with innuendo, arouse suspicion, confuse others, and be mobile in one's identity seemed impossible in a context where categories of sexual identity are salient.

It was precisely because of the characteristics of the French model that five American respondents expressed regretting how life in France limited their ability to display what they described as their authentic sense of self. For example, Alex, a 44-year-old gay American who grew up in Los Angeles and had lived in several French regions for the 15 years before our 
interview, said French discretion about sexual identity was a source of frustration:

On the one hand they say, bon ça nous regarde pas votre sexualité [your sexuality is none of our business], so that's supposed to be very liberating like, $o u f$, I don't have to talk about it. But in real life, friendship, buying an apartment, going out to dinner, buying health insurance, the whole thing, of course who you are with or dating is part of that. So your not being able to share that is very limiting so it's a bit deceiving to say, ça nous regarde pas, and excluding all community identities would be better.

Alex identified very adamantly as gay and only saw inconveniences in the ideology that his sexual identity should remain outside of the realm of everyday social interaction. This tension between his new country and his sexual identity had even been a barrier to integration. Although he had been living in France since the mid-1990s, he said he only started to feel comfortable in the six months before our interview because of his job and despite his sexuality. He said that being gay would "be a positive thing in America."

Jonathan, a 24-year-old American student and performance artist who had been living in Paris for three years, expressed similar limitations to his sexual identity in France. He identified as queer and, before moving to France, participated in non-mainstream gay and alternative queer groups with other performance artists. In France, he said his sexual identity felt limited because there was a lack of visible and organized queer spaces in Paris. As a result, he said he had a sense of divide between national and sexual selves: "the queer self that I identify with does not feel like that of a French queer self." His feelings were confirmed during a summer tour of his 
show in the U.S.: "I just had this great great summer and a lot of that had to do with my queer friends that I was with and I was like, 'Oh God, this is how I feel sort of most at ease in my sexuality,' and I don't think that I have ever felt that ease here in France.” The inability to find people in Paris who share a social and professional life organized around a shared queer identity made Jonathan feel like his “queer self” was incompatible with France.

These respondents developed a sense of sexual self that aligned with the expectations and norms of their countries of origin. Migrating abroad gave them the ability to articulate clearly why they felt more comfortable in their sexual subjectivities before moving but also constrained them from enacting their preferred sexual identities. Common to them was the sense that in their original countries they were less different and more integrated. Their narratives support theories that socialization processes determine sexual identity when individuals draw on local cultural repertoires to create their sense of sexual self. However, interviews with individuals whose preferred sexual model is different from their original culture suggest a more complicated relationship between culture and sexual identity.

\section{When country of origin and preferred sexual identity model conflict}

Six of the French respondents - especially the three who said they came to realize that they were attracted to people of the same sex because of their migration to the United States told me they preferred the American model of sexual identity. Margot, for example, a 30-yearold Black woman, moved to New York from Paris in 2005 in order to advance her career as an actress because she felt that French theatre had no role-models for Black female actresses. She 
said these new opportunities abroad also gave her confidence to explore a side her of sexuality attraction to women - that she never acknowledged in France. Margot explained, "I mean as it was happening to me here I was really aware that if I was still in France it would not have been happening...And I think French people, and I know I am still, you know like, I think we are very judgmental." Realizing that she was bisexual, and feeling confident in her newfound identity, Margot felt it was important to tell two close French friends back home about this part of herself: We were on Skype and they were both like, why do you feel like you have to announce it. So what? Next week we're going to the movies right? And I'm like, guys, I understand this is your utopic world but you know I have to tell you because if I came to your house hand in hand with a girl you'd be like, hmm? So thank you very much for your support, but I do have to announce it.

Margot's French friends could not understand why she would need to declare her bisexual identity to them. They viewed it as inconsequential and unimportant and, according to the French model, Margot should not insist upon or make her sexual difference explicit. For Margot however, after coming to see how things worked in the U.S., this French ideal of not informing her friends seemed inauthentic.

For Marie and Cédric, coming to realize they were attracted to people of the same sex in the United States caused a strong sense of division between their new sexual identities and their national identities. They saw their embrace of a clear identity category as only possible in the U.S. and as directly in conflict with the expectations of their French upbringing. Marie said that once she arrived in the U.S. after law school, she met gays and lesbians working as a lawyer for a 
major civil liberties advocacy organization and started to socialize at bars and clubs, eventually realizing her attraction to women. She described how it "felt so freeing. So completely freeing. Like I'm really myself. I don't think I could ever feel this way if I hadn't left France." Marie could never identify herself with images of lesbians in France: "I had no point of reference, expect of popular cultural images of French lesbians like, really bad ones. Like Muriel Robin [a recently out lesbian French stand-up comedian who has a masculine gender presentation]." Meeting American lesbians through community organizations in Los Angeles gave her an image of a sexual identity she felt more closely represented who she discovered she was. When she told her friends back in France, some of whom were lesbians themselves, about these activities, they asked her, "Why do you need to segregate yourself from the rest of people?" In their eyes, Marie said, she had been "Americanized" and was betraying her roots. She felt conflicted between her new "American-style" sexual identity and her national identity:

It bothers me because I came out here so like that part of me was born in America almost like. I don't know how to explain it. It's almost like the American part of me is gay. Otherwise I don't feel American at all. You know, in a year I can apply for citizenship and I'm like, no way, I really don't want to be an American citizen. I don't feel American at all. I feel French like incredibly, I mean, I am French, like that's me but if I think... I can't reconcile it completely with my sexuality. I haven't really figured that one out.

Coming to realize she was attracted to women and then to label herself as lesbian in the U.S. meant that all of Marie's social interactions when she was initially forming her 
lesbian identity occurred through the language and expectations of the U.S. model. Her French identity and lesbian identities were at odds and mutually incompatible. Ironically, only living in the United States could Marie articulate both identities at the same time.

Cédric also saw his gay identity as bounded by the United States and talked of conflict with his national identity and his French friends because of it. Although being gay was "only a small part" of how he identified, he felt more comfortable in the U.S. where he took advantage of gay community activities, joined a gay volleyball team, and generally felt more open about his sexual identity. He described this gay social life to a heterosexual leftwing friend in France:

And she was like, “what's the point of playing volleyball with gay people?” And so I told her that I thought it was great for socialization to actually make gay friends. And she was shocked you know. She said, "but that's exclusive of other people." She thought it was very, well you know, "communitarian" and you know that is a gros mot [bad word] in French ... And so we basically came to this conclusion that maybe I had been Americanized in the sense that I tend to consider it not wrong to be in your community as long as it doesn't shut you off from the rest obviously.

Cédric's French and sexual identity are incompatible because a French person should naturally reject community-based sociality in the name of republican universalism and assimilation. Moreover, his sexual identity had become "Americanized," as he put it, because he came to see himself as gay in the U.S. "I've basically never been gay in France kind of. I've never really lived there as a gay person," he explained. From his perspective, when one affirms a minority 
difference like homosexuality in France, "there is still this idea that you don't really conform to what it means to be French." He sees a fundamental split between his national and sexual identities and, as a result, cannot project a life for himself as a gay man should he return to France.

American respondents living in France who preferred the French model of sexual identity thrived while abroad. They said they were happy to leave behind the constraints of labeling and public disclosure that Bénédicte and Olivier were confronting. Danielle, for example, attributed her coming to realize she is attracted to women to her move from Florida to Grenoble and has since then felt more comfortable as a lesbian in France. She said she preferred how coming to that realization was low-key and private. Danielle had the impression that in the United States, she would have had to emphasize and commemorate her self-discovery: "I can't imagine celebrating that. Not for the fact that you're not proud of who you are. It's just the fact that, who cares? It's your life. It's more of a private thing." She said she prefers living in France in part because she believed the French - unlike Americans - would not make assumptions about a person's sexuality based on things like marching at a Gay Pride event or spending time in the Marais, Paris's reputed gay district.

Jordan said he felt more like himself than he ever did in the United States because, in part, he was unable to pass (Goffman, 1963) as heterosexual there. "In the U.S. it's like I had a scarlet G. You know what I mean? I was definitely gay," he explained. He said he resented how his gender expression, which was more feminine by U.S. standards, assigned him automatically to an identity category in the U.S. He preferred the flexibility he perceived in France: "Here, 
people are capable of compartmentalizing their sexual lives. That, Americans don't do." His sexuality was an ascribed primary identity category in the U.S. that conflicted with his sense of self. When I asked him if he would use a word to describe his sexual attractions he said, "Homosexual would be ideal. It's clinical. It's a classification of a certain kind of behavior. You know what I mean? If homosexual were more typical [in the U.S.], I would use homosexual because I think litigiously speaking, that is as faithful as you can get to describing it. There isn't one identity." In France, where the word homosexuel is not stigmatizing like it is in the United States, Jordan could emphasize sexuality as a behavior - rather than an identity - and thus said he was more at ease because of it. Moreover, he said he could live openly in France with his long-term partner without having to publicly affirm or adhere to the idea that his desires and behavior should constitute an integral part of his self-understanding.

Dan also preferred France for its different masculinity codes - which may allow some gay men to pass as straight more easily - and its discretion. "I can imagine it being very easy for instance for the person who is considered ... homosexual in America passing for a straight person [here]. Or even if it's not, there's a little discretion... It just doesn't spill into the interaction you have with a person," he explained. Dan appreciated that people would never dare to ask him if he were gay even if they thought it. He felt more aligned with the idea that sexuality should not be anyone's identity. When asked to put a name to his sexual attractions, he said: "Homosexual, I guess, yeah. I don't have an identity. In French I say homosexuel. ... In America I don't like using those words. In America I'll tell people, 'I don't play for that team' or something. I would never say, well 'I'm gay." Like Jordan, Dan feels much more comfortable in France than in the 
U.S.: "I can tell you that I feel a million times more at home here than I ever did in America... When I go to America, I feel so foreign and I feel like so many things to me are foreign.” Dan was integrated in France and because his stance on sexual identity was congruent with "French" patterns of sexual discretion, he felt more like himself when in France than in the U.S. Moreover, because Dan preferred not to foreground his attraction to men or identify as "gay," he expressed feeling more authentically French and personally fit into the ideal of universalism. Of course being both White, male, and middle-class made it even easier for him to feel integrated in France where having a gay identity would have been the only thing to set him apart from the ideal of universalism. Yet despite his privilege, like Marie and Cédric, he could not reconcile his sexual identity - concordant with the French model - with his national identity and even said he was less American because of it.

The narratives of this group reveal a complex relationship between cultural context and sexual identity. The respondents speak of strong disconnections between their sexual and national identities because they rejected the norms, expectations, and values of their upbringing and felt more comfortable in their sexual selves in a country that espoused a very different model. Furthermore, they expressed feeling less different and more integrated when abroad. This group of migrants never saw themselves reflected in the images, stereotypes, or language around sexual minorities from their home countries. For those respondents who had never acknowledged their own same-sex attractions, the new cultural context directly enabled their ability to think about themselves in novel ways and, significantly, to integrate the identity model of the country where they realized their attractions. For those who had already acknowledged their same-sex 
attractions, they formulated sexual identities in spite of and at odds with the dominant models in their countries of origin. This would suggest that the dominant model of their original cultural context did not shape their sexual identity as it did for those in the first group. Rather, other factors led them to form a sexual identity that was more adapted for another country.

\section{Conclusion}

Privileged French and American sexual minorities migrating between each other's countries described systematic cross-national differences in the social organization of sexual identity. Through interactions with friends, acquaintances, and colleagues in both countries, they confronted the idea that in France they should minimize their sexuality to a private practice rather than public status, while in the U.S., they should elevate and publicly express their sexuality as an integral and essential part of their identity. The idea that Western Europe and North America share identical sexual systems is thus belied by the salient characteristics that diverge between countries like France and the United States. Moreover, even White middle-class people who are supposedly at the center of this Western definition of sexual identity can be sensitive to and influenced by national specificities in shaping their subjectivities.

These interviews suggest, however, that the relationship between sexual identity and cultural context is more complex than a simple reproduction of the national model into which individuals are socialized. If such were the case, all of the respondents would have expressed preferences for the models of sexual identity from their countries of origin. Indeed, slightly less than half the sample demonstrated such concordance. For them, it appears that living abroad only 
affirmed their preferences for the model that they adopted before moving. However, over half of the other respondents were much more inclined to adhere to the characteristics of the model of their host country. Nevertheless, these data also undermine the claim that migrants assimilate into the norms of their host countries. Rather, these narratives suggest that a more nuanced and sophisticated explanation of the relationship between cultural and sexual identity is necessary. By uncovering the contradictions, struggles, and dialectical processes that accompany migrants as they make sense of the sexual selves in new places, this paper lays the groundwork for such theorization.

Taken together, it would appear that some individuals who come to express and understand their sexual attractions in a particular cultural context are more likely than others to fully integrate, accept, and defend the model of sexuality where that identity work happens. In other words, the period during which people construct their sexual selves as they realize their attractions to members of the same sex constitutes a crucial moment for solidifying culturally specific repertoires around sexual identity. Moreover, these repertoires can become deeply engrained in their overall sense of self. This can explain why some migrants who do this identity work before moving express feeling ill at ease and frustrated in their sexual identity in a different context. It can also explain why people who experience that crucial moment of self-realization abroad say that their sexual selves belong to that other culture.

Some individuals, however, appear to construct a sense of sexual identity that radically differs from their cultural context. During the period of sexual self-construction, something prevents them from adopting the local cultural model as their peers do. I propose several 
hypotheses for the causes of this surprising and unexpected phenomenon. First, it could be an artifact of the data. A single interview is unable to capture how sexual identity changes over time. Thus, respondents like Jordan, an American who had embraced his sexuality before moving but thought about his identity in particularly French ways, may not articulate changes they experienced in their sexual identities that occurred before or after they moved abroad. This then gives the impression that they never adopted the model from the country of origin. Second, - supposing that they did accurately remember how they constructed their sexual identities despite the claims of all of the respondents that France and the U.S. have single national models of sexual identity, individuals can draw on less popular models that circulate within the same cultural landscape. For instance, some American sexual minorities engage in same-sex sexual practices without self-identifying as gay (Seidman, 2002) while some French gay and lesbian activists adhere to the idea that homosexuality constitutes the grounds for identity formation (Martel, 1996). Third, some respondents may reject local modes of being and labels associated with sexual minorities in order to resist stigma. For instance, Dan's experiences with discrimination and anti-gay attitudes growing up in Louisiana and Jordan's experiences with harassment because of gender nonconformity likely led them to downplay their sexuality and even reject it as basis for identity.

The narratives of these respondents also show that - as has been suggested in noncomparative case studies of sexual minorities of color (Amari, 2013; Moore, 2010; Provencher, 2011) - in France and the United States, the ordering and priority of sexual identities with other kinds of identities is different. Specifically, in France, because sexual identity is treated as 
private - and ideally nonexistent - it cannot easily be placed on equal footing with national identity. In the U.S., because sexual identity is treated as fixed, stable, and politically salient, it cannot be easily subsumed or placed below other identities on a hierarchy. As Xavier stated, identities in the United States are hyphenated. These differences in identity hierarchies explain why many French respondents who adopted the American model of sexual identity struggled much more to reconcile the tension between their national and sexual identities than did American respondents adopting the French model. For the former group, elevating their sexuality to the status of an identity was more politically fraught because they said they were betraying their obligation to put their national identity ahead of all others.

Some have noted that supporting the idea of gay and lesbian identities can inadvertently uphold systems of oppression, reify gender norms, stigmatize people outside of the gay mainstream, and undermine the revolutionary potential of truly radical sexual liberation (Gamson and Moon, 2004; Halperin, 2003; Warner, 1999). By pinning down and disciplining sexual desire and practice into sexual identities, they argue, something is lost. Some might look to France as a source of inspiration for moving beyond the trappings of identity. Indeed, the responses of some of the respondents in this study reveal how a context that de-emphasizes identity can be experienced as liberating. However, the narratives of those who found the French model oppressive warn us to think carefully about life in such a context. If the experiences of these migrants are any indication, despite evidence suggesting that we are moving into a "post-gay" era, such a future in the United States still seems relatively distant (Ghaziani, 2011).

The narratives of these privileged sexual minority migrants confirm what migration 
scholars have found for other groups: sexual practice and identity are an essential component for fully explaining migration and assimilation processes. Looking at their economic and social situations, the French and American migrants studied here have ostensibly successfully integrated into their host countries. However, the struggles and negotiations around their sexual subjectivities reveal a nexus between national identity and sexual identity that belies a story of straightforward integration. I argue, therefore, that sexual self-understanding should not be overlooked even when - as is the case with privileged migrants - it is assumed to be irrelevant. To that end, analyses of sexuality and migration must not be limited to sexual minorities. On the contrary, as scholars have already shown (González-López, 2005; Mai and King, 2009), studying the sexual lives of heterosexuals can shed new light on old questions.

Future research should conduct systematic cross-national comparison on non-migrants because they might in fact reveal more similarities than differences in the experiences and narratives of French and American sexual minorities. Indeed, I would argue that individuals who cross borders might exaggerate national cultural differences because of migration. Future research is also likely to reveal that circumstances in France and the United States have evolved rapidly and may impact the models described by the individuals interviewed for this study. Since these interviews were conducted, France has legalized marriage and adoption for same-sex couples. Growing numbers of politicians and celebrities have revealed their homosexuality. Such changes may make affirming a minority sexual identity less stigmatized in France today. In the United States, marriage for same-sex couples has continued to spread on the state level, the Federal statute banning federal recognition of same-sex marriage has been declared 
unconstitutional by the Supreme Court.Athletes and other public figures continue to reveal their sexual identity. As a result, the social differences that maintained the boundaries around minority sexual identity in the United States may begin to fade.

This study draws our attention to how nationally specific solutions to the liberal tensions between the individual and collective or the public and private shape how people understand their sexuality. Building on the work of sociologists who show that gender, race, ethnicity, geography, and class mutually constitute sexual identity, it argues that broad cultural models also shape identity not only for those at the margins but also for those at the center. Even from places of privilege, middle-class sexual minorities experience pressures that constrain certain kinds of identities in some national contexts but enable them in others. Finally, it highlights how sexual identity is not always fluid and shifting depending on the context but that it can be relatively fixed and stable despite transitions and can sometimes be quite at odds with cultural and social expectations.

\title{
Acknowledgements
}

I thank the interviewees for sharing their stories as well as Abigail Saguy, Mignon Moore, Kristen Schilt, Anthony Ocampo, Samantha Buker, Nicolas Durand, and the anonymous reviewers who pushed this work into exciting new directions. This research was supported by a UCLA Chancellor's prize. An earlier version of this paper was presented under the title "Same Sex, Different Nation: French and American Expatriate Accounts of Sexual Identity" at the 2010 annual meeting of the American Sociological Association in Atlanta, GA.

\begin{abstract}
About the Author
Michael Stambolis-Ruhstorfer is a doctoral candidate in Sociology at UCLA. His dissertation compares the construction and use of "expertise" during legislative and judicial debates around
\end{abstract}


marriage and parenting rights for same-sex couples in France the United States since 1990.

\section{Work Cited}

Altman, D. (2001) Global Sex. Chicago: University of Chicago Press.

Amari, S. (2013) (Ne pas) dire l'homosexualité chez des lesbiennes maghrébines et d'ascendance maghrébine en France. Modern \& Contemporary France 21(2): 219-235.

Bernstein, M. (1997) Celebration and Suppression: The Strategic Uses of Identity by the Lesbian and Gay Movement. The American Journal of Sociology 103(3): 531-565.

Bernstein, M. (2011) United States: Multi-Institutional Politics, Social Movements, and the State. In: Tremblay, M., Paternotte, D., and Johnson, C. (eds.) The Lesbian and Gay Movement and the State: Comparative Insights into a Transformative Relationship. Burlington, VT: Ashgate, pp.197-212.

Berry, C. (2001) Asian Values, Family Values. Journal of Homosexuality 40(3-4): 211-231.

Biegel, S. (2011) Unfinished Business: The Employment Non-Discrimination Act (ENDA) and the K-12 Education Community. New York University Journal of Legislation and Public Policy 14: $357-413$.

Bleich, E. (2011) The freedom to be racist?: How the United States and Europe struggle to preserve freedom and combat racism. New York: Oxford University Press.

Boston, N. (forthcoming) The Amorous Migrant.

Brekhus, W. (2003) Peacocks, Chameleons, Centaurs: Gay Suburbia and the Grammar of Social Identity. Chicago: University of Chicago Press.

Broqua, C. (2005) Agir pour ne pas mourir!: Act Up, les homosexuels et le sida. Paris: Presses de Sciences Po.

Broqua, C., Lert, F. and Souteyrand, Y. (2003) Homosexualités au temps du sida. Paris: EDK.

Brown, W. (2006) Power After Foucault. In: Dryzek, J. S., Honig, B., and Phillips, A. (eds.) The Oxford handbook of political theory. New York: Oxford University Press, pp.65-84.

Brubaker, R. (1992) Citizenship and nationhood in France and Germany. Cambridge, MA: Harvard University Press.

Butler, J. E. and Walter, J. J. C. (1991) Transforming the Curriculum: Ethnic Studies and 
Women's Studies. Albany, NY: SUNY Press.

Cantú, L., Naples, N. A. and Vidal-Ortiz, S. (2009) The Sexuality of Migration: Border Crossings and Mexican Immigrant Men. New York: New York University Press.

Carrillo, H. (2004) Sexual Migration, Cross-Cultural Sexual Encounters, and Sexual Health. Sexuality Research and Social Policy: Journal of NSRC 1(3): 58-70.

Chauncey, G. (1994) Gay New York: Gender, Urban Culture, and the Making of the Gay Male World, 1890-1940. New York: Basic Books.

Collins, D. (2009) We're There and Queer. Gender \& Society 23(4): 465-493.

D'Emilio, J. (1998) Sexual Politics, Sexual Communities: The Making of a Homosexual Minority in the United States, 1940-1970. 2nd ed Chicago: University of Chicago Press.

Decena, C. U. (2011) Tacit subjects: Belonging and same-sex desire among Dominican immigrant men. Durham NC: Duke University Press.

Eliason, M. J. (1996) Identity Formation for Lesbian, Bisexual, and Gay Persons. Journal of Homosexuality 30(3): 31-58.

Ezekiel, J. (2002) Le Women's Lib: Made in France. European Journal of Women's Studies 9 345-361.

Fassin, E. (2001) Same Sex, Different Politics: 'Gay Marriage' Debates in France and the United States. Public Culture 13 215-232.

Fillieule, O. and Duyvendak, J. W. (1999) Gay and Lesbian Activism in France: Between Integration and Community-Oriented Movements. In: Adam, B. D., Duyvendak, J. W., and Krouwel, A. (eds.) The global emergence of gay and lesbian politics: National imprints of a worldwide movement. Philadelphia, PA: Temple University Press, pp.184-213.

Fraser, N. (1989) Unruly practices: Power, discourse, and gender in contemporary social theory. Minneapolis: University of Minnesota Press.

Gagnon, J. H. and Simon, W. (1973) The Social Origins of Sexual Development. In: Kimmel, M. S. and Plante, R. F. (eds.) Sexualities: Identities, Behaviors, and Society. New York: Oxford University Press, pp.29-38.

Gamson, J. and Moon, D. (2004) The Sociology of Sexualities: Queer and Beyond. Annual Review of Sociology 30(1): 47-64.

Ghaziani, A. (2011) Post-Gay Collective Identity Construction. Social Problems 58(1): 99-125. 
Glaser, B. G. and Strauss, A. L. (1967) The Discovery of Grounded Theory; Strategies for Qualitative Research. Chicago: Aldine.

Goffman, E. (1963) Stigma; Notes on the Management of Spoiled Identity. Englewood Cliffs, N.J: Prentice-Hall.

González-López, G. (2005) Erotic Journeys: Mexican Immigrants and Their Sex Lives. Berkeley: University of California Press.

Gunther, S. E. (2004) Building a More Stately Closet: French Gay Movements since the Early 1980s. Journal of the History of Sexuality 13 326-347.

Gunther, S. E. (2009) The Elastic Closet: A History of Homosexuality in France, 1942-Present. Houndmills, Basingstoke, Hampshire: Palgrave Macmillan.

Haider-Markel, D. P. and Meier, K. J. (1996) The Politics of Gay and Lesbian Rights: Expanding the Scope of the Conflict. The Journal of Politics 58 332-349.

Halperin, D. M. (2003) The Normalization of Queer Theory. Journal of Homosexuality 45(2-4): 339-343.

Harper, S. and Reskin, B. (2005) Affirmative Action at School and on the Job. Annual Review of Sociology 31(1): 357-379.

Heckathorn, D. D. (2002) Respondent-Driven Sampling II: Deriving Valid Population Estimates from Chain-Referral Samples of Hidden Populations. Social Problems 49(1): 11-34.

Herdt, G. H. (1997) Same Sex, Different Cultures: Gays and Lesbians Across Cultures. Boulder, CO: Westview Press.

Hondagneu-Sotelo, P. (1994) Gendered transitions: Mexican experiences of immigration. Berkeley CA: University of California Press.

Izienicki, H. (2009) Not There: The Ostensible Absence of Same-Sex Desire in the Polish Immigrant Community in Chicago. Paper presented at the American Sociological Association Annual Meeting; 7 August, San Francsico, CA.

Jackson, J. (2009) Living in Arcadia homosexuality, politics, and morality in France from the liberation to AIDS. Chicago, IL: University of Chicago Press.

Kimmel, M. S. (ed.) (2007) The sexual self: the construction of sexual scripts. Nashville, TN: Vanderbilt University Press.

Lamont, M. (1992) Money, Morals, and Manners: The Culture of the French and American 
Upper-Middle Class. Chicago, IL: Chicago University Press.

Lamont, M. and Molnár, V. (2002) The Study Of Boundaries In The Social Sciences. Annual Review of Sociology 28(1): 167-195.

Lamont, M. and Thévenot, L. (eds.) (2000) Rethinking Comparative Cultural Sociology: Repertoires of Evaluation in France and the United States. Cambridge UK: Cambridge University Press.

Lovaas, K. E., Elia, J. P. and Yep, G. A. (2006) Shifting Ground(s). Journal of Homosexuality 52(1-2): 1-18.

Mai, N. and King, R. (2009) Love, Sexuality and Migration: Mapping the Issue(s). Mobilities 4(3): 295-307.

Manalansan, M. F. (2003) Global Divas: Filipino Gay Men in the Diaspora. Durham, N.C: Duke University Press.

Martel, F. (1996) Le Rose Et Le Noir: Les Homosexuels en France Depuis 1968. Paris: Seuil.

McCaffrey, E. (2005) The Gay Republic: Sexuality, Citizenship and Subversion in France. Aldershot, UK: Ashgate.

Miles, M. B. and Huberman, A. M. (1984) Qualitative Data Analysis: A Sourcebook of New Methods. Beverly Hills: Sage Publicaions.

Moore, M. R. (2010) 'Black and Gay in L.A.': The Relationships Black Lesbians and Gay Men have with their Racial and Religious Communities. In: Hunt, D. and Ramon, A.C. (eds.) Black Los Angeles: American Dreams and Racial Realities. New York: NYU Press, pp. 188-214.

Moore, M. R. (2011) Invisible Families: Gay Identities, Relationships, and Motherhood Among Black Women. Los Angeles, CA: University of California Press.

Mucciaroni, G. (2008) Same Sex, Different Politics: Success and Failure in the Struggles Over Gay Rights. Chicago: University of Chicago Press.

Nagel, J. (2000) Ethnicity and Sexuality. Annual Review of Sociology 26(1): 107-133.

Ocampo, A. C. (2012) Making masculinity: Negotiations of gender presentation among Latino gay men. Latino Studies 10(4): 448-472.

Patton, C. and Sánchez-Eppler, B. (eds.) (2000) Queer Diasporas. Series Q Durham, N.C: Duke University Press. 
Pierceson, J. (2005) Courts Liberalism And Rights: Gay Law And Politics In The United States and Canada. Philadelphia, PA: Temple University Press.

Poon, M. K.-L. and Ho, P. T.-T. (2008) Negotiating Social Stigma Among Gay Asian Men. Sexualities 11(1-2): 245-268.

Poulin-Deltour, W. J. (2004) French Gay Activism and the American Referent in Contemporary France. The French Review 78(1): 118-125.

Provencher, D. M. (2011) Coming Out à l'oriental: Maghrebi-French Performances of Gender, Sexuality, and Religion. Journal of Homosexuality 58(6-7): 812-833.

Provencher, D. M. (2007) Queer French: Globalization, Language, and Sexual Citizenship in France. Aldershot, UK: Ashgate.

Rimmerman, C. A. (2002) From identity to politics: The lesbian and gay movements in the United States. Philadelphia, PA: Temple University Press.

Saguy, A. C. (2003) What is Sexual Harassment?: From Capitol Hill to the Sorbonne. Berkeley, CA: University of California Press.

Scott, J. W. (2005) Parité!: Sexual Equality and the Crisis of French Universalism. Chicago, IL: The University of Chicago Press.

Scott, J. W. (2009) The Politics of the Veil. Princeton, NJ: Princeton University Press.

Seidman, S. (2002) Beyond the closet: The transformation of gay and lesbian life. New York: Routledge.

Stychin, C. F. (2003) Governing sexuality: The changing politics of citizenship and law reform. Oxford, UK: Hart.

Swidler, A. (1986) Culture in Action: Symbols and Strategies. American Sociological Review 51(2): 273-286.

Valocchi, S. (1999) The Class-Inflected Nature of Gay Identity. Social Problems 46 207-224.

Walsh, K. (2007) 'It got very debauched, very Dubai!' Heterosexual intimacy amongst single British expatriates. Social \& Cultural Geography 8(4): 507-533.

Warner, M. (1999) Normal and Normaller: Beyond Gay Marriage. GLQ 5(2): 119-172.

Wong, D. (2010) Hybridization and the Emergence of "Gay" Identities in Hong Kong and in China. Visual Anthropology 24(1-2): 152-170. 


\section{Table 1: Sample Characteristics $(n=23)$}

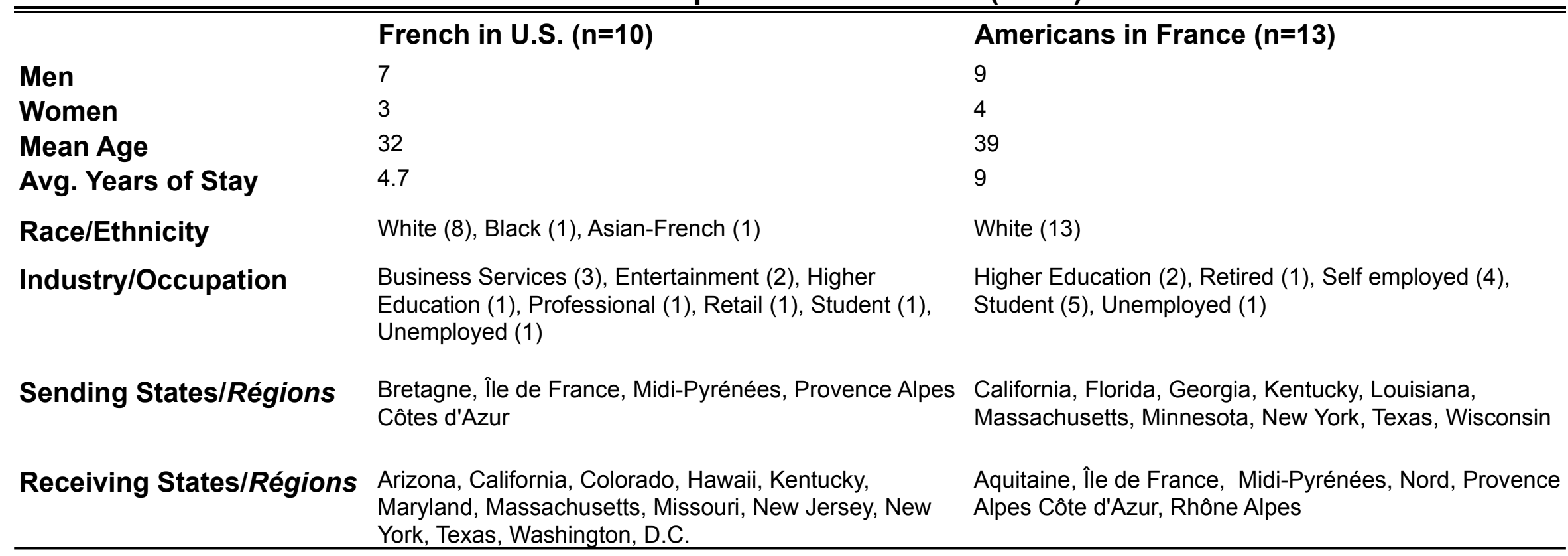




\section{Table 2: Concordance/Discordance of Country of Origin and Prefered Sexual Identity Model}

\begin{tabular}{lcc}
\hline \hline & \multicolumn{2}{c}{ Origin and Current Location } \\
$\begin{array}{lcc}\text { Prefered Sexual } \\
\text { Identity Model }\end{array}$ & French in U.S. & American in France \\
French & 4 (Concordance) & 8 (Discordance) \\
American & 6 (Discordance) & 5 (Concordance) \\
\hline Total respondents & 10 & 13 \\
\hline
\end{tabular}

